\title{
STRUKTURA RASCJEPA I PARLAMENTARNI IZBORI U HRVATSKOJ 2020. U DOBA PANDEMIJE
}

\author{
Višeslav Raos \\ Fakultet političkih znanosti \\ Sveučilišta u Zagrebu \\ E-mail: viseslav.raos@fpzg.hr
}

DOI: 10.20901/an.17.01

Izvorni znanstveni rad

Prihvaćeno: listopad 2020.

\begin{abstract}
Sažetak Na temelju rezultata predizborne terenske ankete, autor istražuje strukturu društvenih rascjepa u Hrvatskoj u kontekstu parlamentarnih izbora 2020. Multinominalnom logističkom regresijom ispituje dosadašnje spoznaje o vrijednosnom rascjepu utemeljenu u religiji i identitetskom rascjepu utemeljenu na odnosu prema prošlosti, koji tvore kulturnu dimenziju stranačkog natjecanja. Testira se i moguća pojava novoga društvenog rascjepa ukorijenjenoga u razlikama u stavovima birača o ekonomskim pitanjima, kao i rascjepa vezana za pitanja suverenizma i zahtjeva za većom demokratskom participacijom. Istraživanje uvodi nove prediktorske ljestvice koje dosad nisu korištene u sličnim istraživanjima hrvatskih izbora. Evaluacija predloženoga regresijskog modela pokazala je kako su religioznost i odnos prema prošlosti ostali dominantni prediktori ponašanja birača u Hrvatskoj. Potvrđene su i značajne dobne razlike u ponašanju, pri čemu mlađi birači vjerojatnije podržavaju Domovinski pokret ili apstiniraju, a stariji birači vjerojatnije glasuju za koaliciju lijevog centra. Nalazi pokazuju kako se s porastom vrijednosti na ljestvici populizma smanjuje vjerojatnost glasovanja za HDZ. Zaključno se potvrđuju stabilnost vrijednosnoga i identitetskog rascjepa te značenje religije i prošlosti, ali se ne utvrđuje postojanje ekonomskoga rascjepa.
\end{abstract}

Ključne riječi Hrvatska, parlamentarni izbori, društveni rascjepi, biračko ponašanje, političke stranke

\section{Uvod}

Dosadašnja istraživanja dinamike stranačkog natjecanja i strukture društvenih rascjepa u Hrvatskoj opetovano su pokazala kako se biračke preferencije strukturiraju na "ideološko-kulturnoj i povijesno-identitetskoj dimenziji", dok je uloga društvenog rascjepa koji bi bio utemeljen na razlikama u ekonomskim stavovima, interesima i identitetima izrazito slabo izražena (Henjak, Čular i
Zakošek 2013: 462-463). Dolenec (2012) pak zaključuju kako socijalno-ekonomski rascjep postoji u hrvatskom društvu, ali nije predstavljen u parlamentarnoj stranačkoj areni, što interpretira kao problem adekvatnosti političkog predstavništva. Novija istraživanja (Ančić, Baketa i Kovačić 2019) također pokazuju kako postoji veza između socijalno-ekonomskoga (klasnog) statusa i razine i kakvoće političke participacije, ali se to još ne pretače u ekonomsku 
dimenziju strukturiranja biračkih preferencija. Neki su autori ustvrdili kako ne postoji socijalno-ekonomski rascjep, nego birači svoje stavove o ekonomskim pitanjima oblikuju sukladno otprije uspostavljenim afinitetima prema određenima političkim strankama, kao što se dogodilo u izborima 2007. i tada važnom pitanju uvođenja poreza na nekretnine (Henjak 2007: 86).

Henjak, Zakošek i Čular (2013: 463464) ističu da su stupanj religioznosti i obiteljsko povijesno naslijeđe iz Drugoga svjetskog rata najvažniji čimbenici koji određuju strukturiranje birača uzduž ideološko-kulturnoga i povijesno-identitetskoga društvenog rascjepa, koji zajedno čine kulturnu dimenziju stranačkog natjecanja. Razina religioznosti pokazala se stabilnim prediktorom glasovanja, čak ako se uzmu u obzir i dobne razlike, odnosno očekivanje da će kod mlađih birača taj čimbenik biti manje izražen, dok je odnos prema prošlosti kod mlađih birača, posebice onih na ljevici, s protokom vremena ponešto oslabio (Henjak, Zakošek i Čular 2013: 465-466).

U jednoj starijoj raspravi o prirodi stranačkog sustava u Hrvatskoj i pravcima njegova razvoja, Čular (2004: 139) potvrđuje ključnu ulogu religioznosti, ali i detektira smanjenje važnosti autoritarnosti kao prediktora biračkih preferencija, što se može protumačiti kao posljedica demokratske konsolidacije i opće prihvaćenosti demokracije kao "jedine igre u gradu" (Linz i Stepan 1996: 5). Također, predviđa eventualno otvaranje novog rascjepa između pobornika globalizacije i nadnacionalnog odlučivanja i udruživanja, s jedne, te zagovornika nacionalnoga suverenističkog pristupa, s druge strane (Čular 2004: 142). Recentno longitudinalno istraživanje normativne i praktične potpore demokraciji razotkrilo je pak jaz koji se otvara s izborima 2015. te otvorilo pitanje o dosezima demokratske konsolidacije u Hrvatskoj (Čular i Šalaj 2019: 17). Ti nalazi potiču na ponovno ispitivanje autoritarnosti kao mogućeg prediktora biračkih preferencija, ali i na razmišljanje o novim varijablama koje bi detektirale razlike na osi pobornici-osporavatelji globalizacije i nadnacionalnog odlučivanja.

Cilj je ovog rada provjeriti strukturiraju li se biračke preferencije u Hrvatskoj još uvijek dominantno uzduž religijskog i povijesnog rascjepa koji proizvode kulturnu dimenziju stranačkoga natjecanja ili, osim te dimenzije, možemo govoriti i o (slabim) naznakama novoga ekonomskog rascjepa, koje se testira pomoću novih pitanja o ekonomskim stavovima. Nadalje, rad uvodi u raspravu o kulturnoj dimenziji stranačkog natjecanja u Hrvatskoj i novu ljestvicu populizma, ali i aktualizira neke starije ljestvice, poput konzervativizma i autoritarnosti. Time se istraživanje odmiče od vrlo često korištene ljestvice lijevo-desno (Čular 1999) te širi dosadašnji "naglasak" u istraživanjima društvenih rascjepa u Hrvatskoj. Uz to, rad provjerava i mogućnost nastanka novog rascjepa utemeljenog u opreci između zagovornika i osporavatelja suverenizma, to jest odlučivanja ponajprije na razini nacionalne države i iz perspektive nacionalne države, kao i rascjepa između zagovaratelja većega demokratskog suodlučivanja građana i onih koji ne smatraju da je ono potrebno, odnosno prihvaćaju zatečeno stanje. Ispitivanje ekonomskog rascjepa, kao i rascjepa koji se strukturiraju oko pitanja suverenizma i demokratske participacije potaknuto je temama koje su u javnosti kružile tijekom dugog razdoblja neformalne pretkampanje za parlamentarne izbore, koja se izravno nastavila na predsjedničke izbore održane krajem prosinca 2019. i početkom 2020. siječnja, kao i za vrijeme sâme izborne kampanje u drugoj polovici lipnja 2020. 
Kontekst izbora 2020.

Izbore za deseti saziv Hrvatskog sabora obilježila je slaba izlaznost, manja od pedeset posto, uvelike uzrokovana ljetnim terminom i strahom dijela birača od izlaska na birališta usred pandemije koronavirusa. Kampanjom nisu prevladavale samo teme vezane za krizno upravljanje, javno zdravstvo i očekivane negativne učinke karantene na gospodarski rast, porezne prihode i stopu nezaposlenosti, nego i bioetička pitanja, poput zakonskog reguliranja prekida trudnoće. Dio poduzetnika, mahom mlađe i srednje generacije, okupljen u udruzi "Glas poduzetnika", stavio je na dnevni red pitanja liberalizacije poslovanja, poreznog sustava i radnog zakonodavstva te potaknuo raspravu o suprotstavljenim interesima zaposlenika u javnome i privatnom sektoru. Uz to, pojavile su se i teme jačanja mehanizama referendumskog odlučivanja, kao i odnosa između suverenizma (unilateralnoga nacionalnog djelovanja i odlučivanja) i europeizma (multilateralnoga nadnacionalnog djelovanja $\mathrm{i}$ odlučivanja). Te su teme posebno naglašavali Most nezavisnih lista i koalicija stranaka okupljenih oko Domovinskoga pokreta Miroslava Škore.

Nakon što su izbori 2015. i 2016. doveli u pitanje dotadašnju razmjerno stabilnu bipolarnu strukturu stranačkog natjecanja (Raos 2015: 9; Grbeša i Šalaj 2017: 11-12) i omogućili parlamentarizaciju dviju novih izazivačkih stranaka, ${ }^{1}$ Mosta nezavisnih lista i Živog zida, koje su privukle birače koji nisu bili jasno vrijednosno opredijeljeni (Henjak 2018:

\footnotetext{
Izazivačke su stranke novi akteri, često organizirani u obliku pokreta ili platforme, uz odmak od klasične stranačke organizacije, koji postavljaju nove teme i predstavljaju se kao beskompromisni borci za "malog čovjeka" od etabliranih stranaka i društvenih elita općenito (De Vries i Hobolt 2020).
}

403), izbori 2020. doveli su do nekoliko međusobno oprečnih procesa. Prvo, parlamentarizirali su se novi politički akteri i na lijevome, i na desnom, i na sredinskom dijelu ideološkog spektra. Time se osnažuje uloga Sabora u duhu ideala razmjernog predstavništva koje bi, načelno, trebalo proizvoditi sastav predstavničkog tijela koji odražava cijelu paletu stavova, identiteta i interesa u društvu. Drugo, HDZ se suočio s Domovinskim pokretom, najsnažnijim izazivačem desno od sebe u posljednjih trideset godina, čiji se vođe obraćaju HDZ-ovu biračkom tijelu s izravnom porukom kako oni primjerenije predstavljaju vrednote HDZ-a od sadašnjeg vodstva stranke. Treće, nasuprot HDZ-u, SDP je ponovno okupio široku koaliciju lijevo od centra, nastavljajući trend koji je počeo s koalicijom "Kukuriku" 2011. Glasovna i mandatna razlika između HDZ-a i SDP-a (s članicama koalicije lijevog centra ili bez njih) značajno se povećala i vratila na razine kakve su postojale prije više od jednog desetljeća. To upućuje na ponovnu aktualizaciju "asimetričnog obrasca mobilizacije" (Henjak 2011), budući da je HDZ-ovo biračko tijelo na izborima 2020. ostalo mnogo stabilnije od biračkoga tijela SDP-a i partnera, unatoč usponu Domovinskog pokreta Miroslava Škore i njegovih partnera.

\section{Podaci i metode}

Istraživanje se temelji na podacima prikupljenima u okviru Hrvatskih izbornih studija, dugogodišnjeg niza predizbornih $\mathrm{i}$ poslijeizbornih terenskih anketa koje na reprezentativnom uzorku od tisuću ispitanika na području cijele Hrvatske provodi Fakultet političkih znanosti Sveučilišta u Zagrebu. Pobliže, $\mathrm{u}$ ovome radu koristim podatke prikupljene $u$ predizbornoj anketi provedenoj početkom 2020. Terensko prikupljanje podataka završeno je sredinom ožujka 
2020, neposredno prije uvođenja javnozdravstvenih mjera izazvanih pandemijom virusa SARS-CoV-2. Analiza je provedena pomoću inačice programskog jezika $R$ 4.0.2., u verziji sučelja $R$ Studio 1.3.1056.

Kao što je spomenuto, izbori 2020. unijeli su novu dinamiku u politiku u obliku parlamentarizacije zelene (Možemo!) i antikapitalističke ljevice (Radnička fronta) te centrističkih liberalnih opcija okupljenih u strankama Pametno, Stranka s imenom i prezimenom i Fokus. No broj ispitanika koji su izrazili preferencije prema tim akterima $\mathrm{u}$ anketi bio je premali da bi mogle biti adekvatno uključene u analizu. Njihova "nevidljivost" u anketi ne čudi uzme li se u obzir da su te opcije najveći rast popularnosti, mjeren telefonskim ispitivanjima javnog mnijenja koja su objavile javne i privatne televizijske kuće, doživjele tek od kraja svibnja pa do sâmih srpanjskih izbora (Bago 2020). Inicijalno je u istraživanje trebao biti uključen Most nezavisnih lista kao četvrtoplasirana lista na nacionalnoj razini. No razmjerno mali broj birača Mosta u ukupnoj anketi otvorio je pitanje stabilnosti analize koja bi uključivala populaciju ispitanika koja bi bila značajno manja od ostalih te su stoga formirane četiri populacije ispitanika. Na temelju anketnog pitanja o namjeri glasovanja za određenu stranku ili koaliciju, ispitanici su grupirani u kategorije "HDZ", "Restart koalicija", "Domovinski pokret" i "Izborni apstinenti". Ispitanici koji su se odlučili za neke druge stranke, isključeni su iz analize.

Prediktori korišteni u analizi uključuju kontinuirane i dihotomne varijable prisutne i u prijašnjima anketnim istraživanjima u projektu Hrvatske izborne

2 Za HDZ se odlučilo 225 ispitanika, za Restart koaliciju 287, za Domovinski pokret 126, dok je izbornih apstinenata bilo 218 . Za Most nezavisnih lista odlučila su se 34 ispitanika. studije (primjerice Henjak, Zakošek i Čular 2013; Henjak 2018), ali i neke koje istraživači nisu koristili u obradi navedenih podataka, kao i nekoliko novih prediktora konstruiranih od čestica koje su prvi put uvrštene u upitnik na temelju kojega je provedena anketa 2020.

Prvi je prediktor ljestvica društvenog konzervativizma koja se, u nešto drugačijem obliku, prvi put pojavila u anketi 2000. Ljestvica izvorno sadržava šest čestica (tablica 6) i daje jedan opći faktor. Za potrebe ovoga istraživanja, posljednja je čestica isključena zbog niske korelacije s ostalim česticama na ljestvici. Cronbachova a za tu skraćenu ljestvicu iznosi vrlo dobrih 0,71 . Drugi je prediktor, također jednodimenzionalan, ljestvica autoritarnosti (tablica 7), koju je u ovom obliku opisao Šiber (1998: 196), a izvorno se temelji na Adornovoj F-ljestvici (Adorno i dr. 1950: 226-227). Koeficijent unutarnje konzistentnosti ( $\alpha$ ) za tu ljestvicu iznosi dovoljnih $0,62 .^{3}$ Treći je prediktor ljestvica populizma koja se temelji na novoj ljestvici populizma koju su razvili Castanho Silva i suradnici. Ona se temelji na devet čestica koje daju tri latentne varijable - democentričnost (people-centeredness), protuelitizam (anti-elitism) i manihejski pogled na svijet ( $\mathrm{Ma}$ nichean outlook) (Castanho Silva i sur. 2019: 160-161). Autori ljestvice predlažu i skraćenu inačicu sa šest čestica (tablica 8), koja daje jedan opći faktor (Castanho Silva i sur. 2019: 166), te je upravo u tome obliku uključena u izbornu anketu 2020. U ovom su istraživanju dvije posljednje čestice izbačene zbog niske koreliranosti s ostatkom ljestvice, tako da

\footnotetext{
3 Novija psihometrijska istraživanja pokazala su da među istraživačima nema suglasja o poželjnima i minimalnim vrijednostima Cronbachove alfe, da kraće ljestvice obično daju niže koeficijente i da je čestice uputno izbacivati ako su izrazito slabo (ili negativno) korelirane s ostatkom ljestvice, a ne samo zato da bismo "napuhali" alfa-koeficijent (Hoekstra i dr. 2019: 353-354).
} 
je naposljetku dobivena skala od četiri čestice, uz Cronbachovu a koja iznosi dovoljnih $0,60 .{ }^{4}$ Četvrti je prediktor nova kratka ljestvica ekonomskog liberalizma (tablica 9), zasnovana na novim pitanjima koja nisu bila uvrštena u prethodne valove istraživanja u sklopu Hrvatskih izbornih studija. Ona se temelji na trima česticama koje mjere sklonost ispitanika tržišnim rješenjima u obrazovanju, stambenoj politici i zapošljavanju. Ljestvica daje Cronbachovu a od dovoljnih 0,62 , a odabir takvih čestica temelji se na očekivanju kako će one jasnije kontrastirati lijeve (više države i javnoga, uz naglasak na društvenoj jednakosti) i desne (manje države i više privatnoga, uz naglasak na osobnoj slobodi) socijalno-ekonomske stavove od općenitijih pitanja o ulozi države u gospodarstvu ili

4 Peta i šesta čestica (tablica 8), koje su izbačene, odnose se na manihejski pogled na svijet. Peta čestica bila je negativno korelirana s ostatkom ljestvice. Autori u opisu postupka stvaranja te nove ljestvice populizma navode kako su u nekim slučajevima, posebice u slučajevima Švicarske i Hrvatske, inicijalna testiranja ljestvice na studentskoj populaciji imala problema $\mathrm{u}$ analizi invarijance (Castanho Silva i sur. 2019: 158-159). Drugim riječima, autori su ustanovili kako su detektirani problemi u psihometrijskoj istovjetnosti mjerenog konstrukta u različitim populacijama/ zemljama (Putnick i Bornstein 2016: 71), što implicira drugačije lokalno (u pojedinim zemljama u kojima se testira mjerni instrument) shvaćanje koncepata koje istraživanje želi zahvatiti. Konačna inačica nove ljestvice populizma dodatno je provjeravana u devet zemalja, a u toj dodatnoj provjeri jedna od čestica koje se vezuju za manihejski pogled na svijet - "Ljudi s kojima se politički razilazim samo su neinformirani" (šesta čestica u skraćenoj ljestvici) - imala je nešto nižu razinu faktorskog zasićenja od ostalih čestica (Castanho Silva i sur. 2019: 160). Uzevši to u obzir, ne treba čuditi što je u ovom istraživanju ljestvica populizma dodatno skraćena, premda takav postupak, sâm po sebi, ne govori ništa protiv opće validnosti i uporabljivosti ljestvice, kako u istraživanjima u jednoj zemlje tako i u komparativnim istraživanjima. prikladnoj visini poreznog opterećenja. Riječ je, dakle, o pokušaju (ponovnog) testiranja prihvaćene teze kako ekonomski stavovi hrvatskih birača ne mogu služiti kao vjerodostojni prediktori njihovih izbornih preferencija.

Uz navedene glavne prediktivne ljestvice, $\mathrm{u}$ istraživanje su uključene varijabla religioznost (zasnovana na učestalosti pohađanja vjerskih obreda) i dvije posve nove varijable: suverenizam (zasnovan na stupnju suglasnosti ispitanika s izjavom "Trebalo bi donositi manje odluka na europskoj razini") $)^{5}$ i demokratska participacija (stupanj suglasnosti s izjavom "Građani u našoj zemlji trebaju više mogućnosti za suodlučivanje"). Uz to, uključena je varijabla dobi, koja se pokazala značajnim prediktorom i u ranijim istraživanjima (primjerice, Henjak 2018).

Stupanj religioznosti pokazao se važnim i u prethodnim istraživanjima, uključivši ona koja zahvaćaju razliku među biračima novih izazivačkih stranaka, poput Mosta nezavisnih lista i Živoga zida, i etabliranih stranaka, poput HDZ-a i SDP-a (Henjak 2018: 397). Dok su neka prethodna istraživanja iz Hrvatskih izbornih studija religioznost mjerila pomoću stupnja suglasnosti sa službenima vjerskim učenjima, sada se mjeri učestalošću sudjelovanja u vjerskim obredima kako bi se zahvatila praktična, a ne samo deklarativna religioznost. Suverenizam, kao ideološka samoidentifikacija i kao opis želje za većim stupnjem odlučivanja na nacionalnoj razini, posljednjih se godina pojavio u nizu europskih zemalja, posebice u kampanji za izbore Europskog parlamenta u svibnju 2019. (Basile, Borri i Verzichelli 2020). Demokratska participacija posljednjih se godina u hrvatskoj javnosti nameće kao važna tema, posebice u kontekstu

Izvorna je varijabla rekodirana kako bi više vrijednosti označavale veći stupanj suglasnosti s navedenom izjavom. 
Tablica 1. Deskriptivna statistika prediktora

\begin{tabular}{lccccccc}
\hline \multicolumn{1}{c}{ Ljestvica } & N & M & SD & Min & $\mathbf{0 , 2 5}$ & $\mathbf{0 , 7 5}$ & Maks \\
\hline Društveni konzervativizam & 856 & 18,29 & 4,16 & 5 & 16 & 21 & 25 \\
Autoritarnost & 856 & 16,78 & 4,03 & 5 & 14 & 19 & 25 \\
Populizam & 856 & 16,82 & 2,65 & 5 & 15 & 19 & 20 \\
Ekonomski liberalizam & 856 & 7,86 & 4,46 & 3 & 4 & 11 & 21 \\
Religioznost & 856 & 2,73 & 1,71 & 1 & 1 & 4 & 6 \\
Dob & 856 & 48,5 & 17,28 & 18 & 33 & 62 & 99 \\
\hline Suverenizam & 856 & 4,47 & 2,06 & 1 & 3 & 6 & 7 \\
Demokratska participacija & 856 & 4,88 & 2,09 & 1 & 3 & 7 & 7 \\
\hline
\end{tabular}

uspona pučkih referendumskih inicijativa (Čepo i Nikić Čakar 2019).

Nadalje, kreirane su dihotomne varijable pobačaj ("Žene trebaju imati pravo slobodno odlučivati o pobačaju, i to treba zajamčiti zakonom"), vjeronauk ("Nastavu vjeronauka treba izvoditi u školama") i privatni sektor (sve kategorije zaposlenih u privatnom sektoru). Reguliranje prava na prekid trudnoće u nekima prijašnjima istraživanjima pokazalo se relativno dobrim prediktorom stranačkih preferencija, posebice $\mathrm{u}$ smislu veze restriktivnijih stavova i preferencija za stranke desno od centra (Bagić 2007: 108; Raos 2019: 22). To pitanje uključeno je $\mathrm{u}$ analizu ponajprije zato što je bilo snažno prisutno u kampanji uoči izbora 2020. Budući da je pitanje smjera, dinamike i strukture kurikularne reforme posljednjih godina postalo novim bojištem normativnih prijepora o odnosa javnog školstva i vjerskih zajednica, posebice Katoličke crkve, uvrštena je varijabla koja mjeri stav o školskom vjeronauku. Premda su neka starija istraživanja (Bagić 2007; Henjak 2007) koristila mnoštvo kategorija profila radnog mjesta kako bi testirala odnos socijalno-ekonomskog statusa i biračkih preferencija, sada je kreirana jedna diho- tomna varijabla na temelju zaposlenja ispitanika u privatnom sektoru kako bi se ispitalo značenje navodne snažne opreke među građanima koji primaju plaću iz proračuna i onih u privatnom sektoru za koje se kaže "da ga pune", na tragu javnih polemika koje su tijekom 2020. zaoštrili predstavnici udruge "Glas poduzetnika", ali i neki mrežni portali skloni dihotomnom tumačenju socijalno-ekonomske stvarnosti u Hrvatskoj.

Uz to su stvorene i tri dummy-varijable za obiteljsko naslijeđe NOB-a ("Obitelj je pretežno djelovala u okviru antifašističkoga partizanskog pokreta"), odnosno $\mathrm{NDH}-\mathrm{a}$ ("Obitelj je pretežno djelovala u domobranskima i/ili ustaškim postrojbama $\mathrm{NDH}$ "), kao i za ispitanike s obiteljskim naslijeđem Domovinskog rata ("Ispitanik i/ili član kućanstva ima braniteljski status"). Obiteljsko naslijeđe Drugoga svjetskog rata uključeno je u analizu kako bi se ispitalo je li "politička biografija obitelji" (Šiber 1997) još uvijek dobar pretkazatelj stranačkih preferencija. No u ovome istraživanju, za razliku od prethodnih sličnih radova (Henjak 2011, 2018), dodano je i naslijeđe Domovinskog rata kako bi se ispitalo u kojoj je mjeri braniteljski status ispitanika ili ispitanikovih ukućana povezan sa 


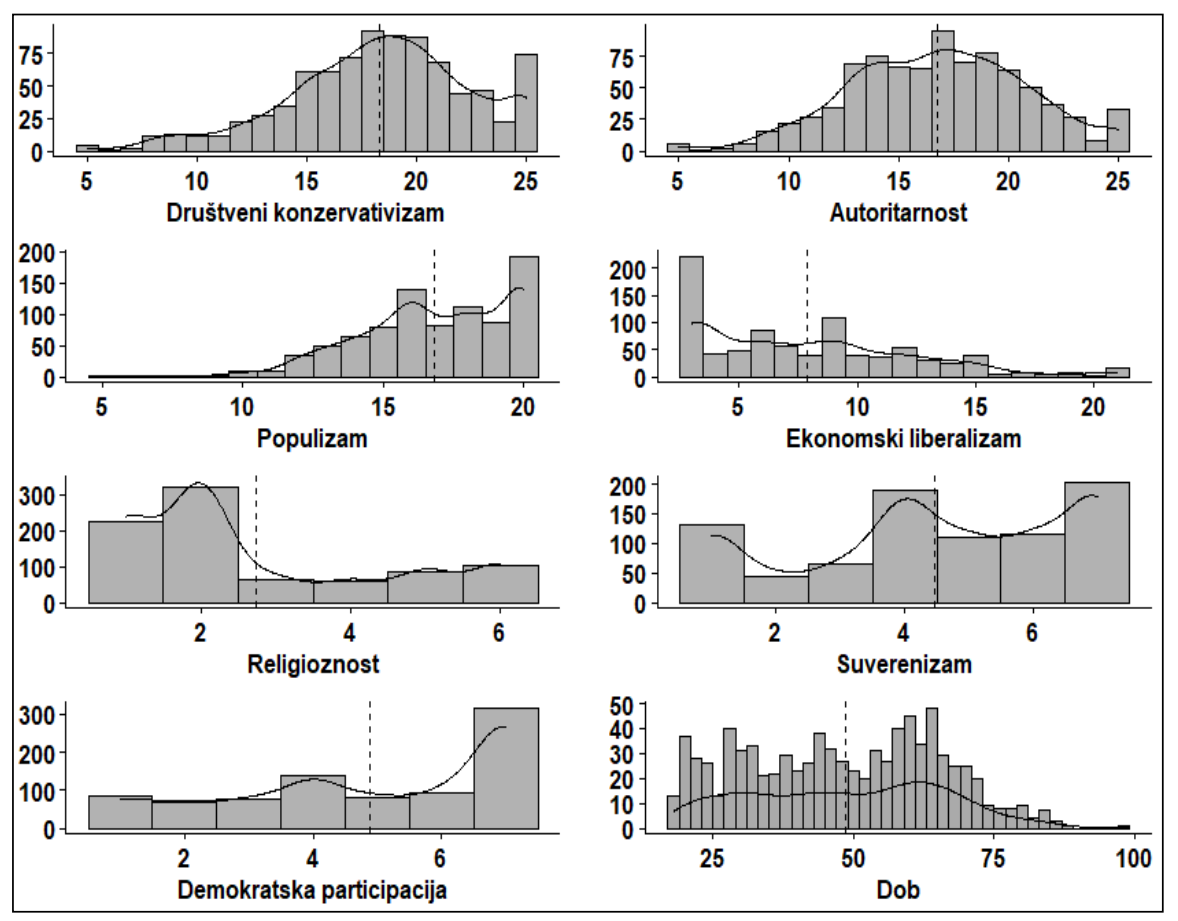

Slika 1. Stupčasti dijagram glavnih prediktora

stranačkim preferencijama, očekujući da će se potvrditi veza braniteljskog statusa i preferencija desno od centra, kao što su to pokazali Bagić i Kardov (2018: 100).

Analiza prezentirana u ovome radu temelji se na multinominalnome logističkom regresijskom modelu s četirima kategorijama na ovisnoj varijabli: $\mathrm{HDZ}$, Restart koalicija, Domovinski pokret, izborni apstinenti. Za iste prediktore izvedene su četiri inačice modela, s referentnim kategorijama za svaki od četiri moguća ishoda na ovisnoj varijabli. U drugom dijelu analize, za one prediktore za koje su dobiveni statistički značajni koeficijenti, prezentirani su i marginalni efekti kako bi se pobliže razjasnilo učinke pojedinih varijabla.

\section{Nalazi i rasprava}

Prije nego što se prikažu i rasprave nalazi regresijskog modela, treba se osvrnuti na distribuciju prediktora (osam ljestvica opisanih u prethodnom odjeljku, v. tablicu 1). Na slici 1 . može se vidjeti kako je distribucija društvenog konzervativizma nakošena udesno, implicirajući općenitu konzervativnu prirodu hrvatskog društva. Nasuprot tome, premda nije normalno distribuiran, prediktor autoritarnost pokazuje mnogo ravnomjerniju distribuciju. Zanimljiv je nalaz za ljestvicu populizma koja je izrazito nakošena udesno (prema većim vrijednostima), što bi značilo da su ispitanici $\mathrm{u}$ anketi izrazito bili skloni iskazivati populističke stavove. Naposljetku, nova ljestvica ekonomskog liberalizma pokazuje obrnutu distribuciju, s izrazitom nakošenošću stupčastog dijagrama ulijevo (niže vrijednosti), što ukazuje na to da je prema ekonomskim stavovima društvo mnogo bliže lijevim pozicijama, dok protržišne stavove, u osjetnoj mjeri, zastupa manjina. 
Tablica 2. Regresijski model 1.

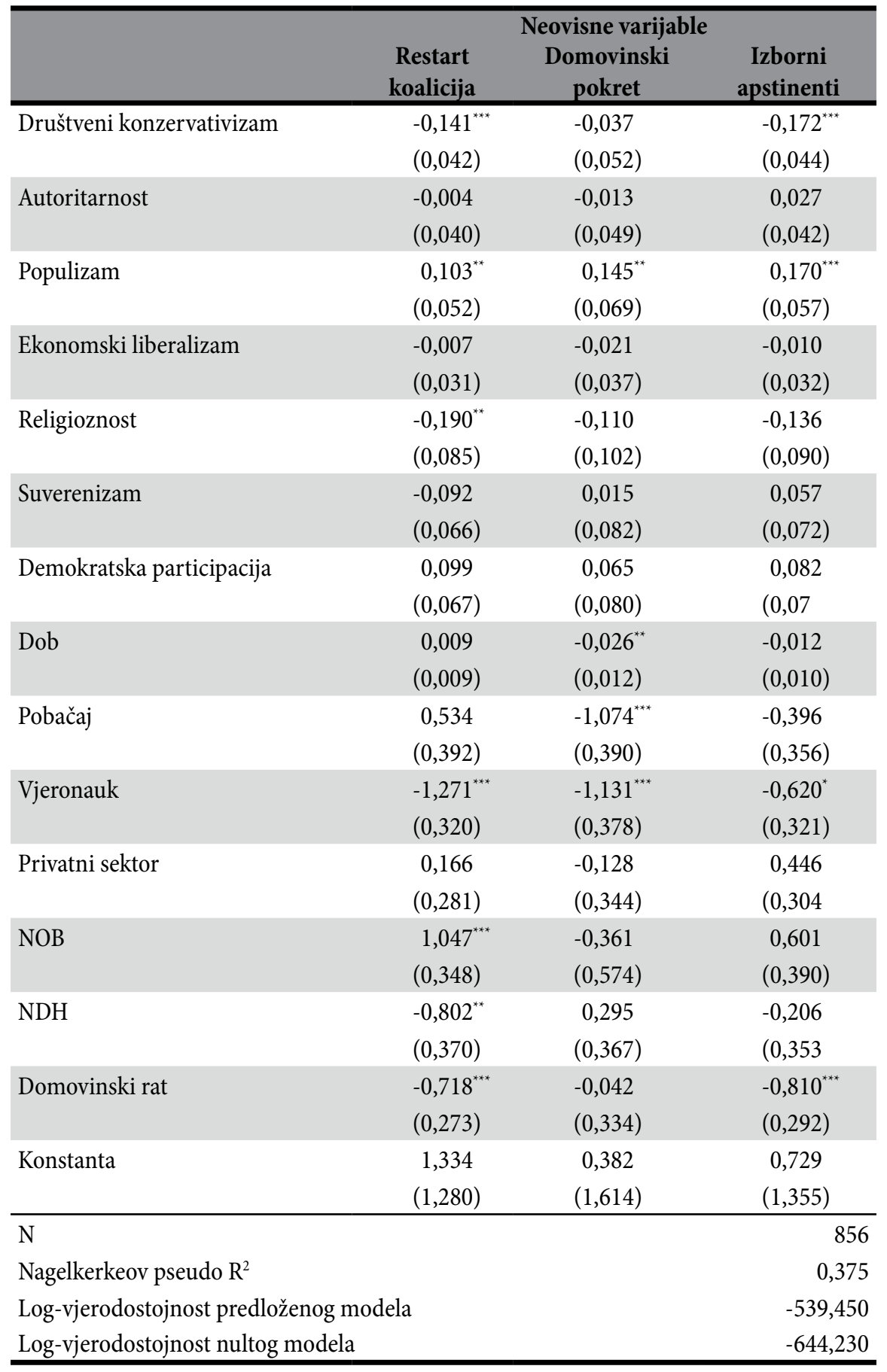

${ }^{\star} \mathrm{p}<0,1 ;{ }^{* *} \mathrm{p}<0,05 ;{ }^{* * *} \mathrm{p}<0,01$

Napomena: referentna kategorija je "HDZ". 
Tablica 3. Regresijski model 2.

\begin{tabular}{|c|c|c|c|}
\hline & HDZ & $\begin{array}{c}\text { ovisne varijal } \\
\text { Domovinski } \\
\text { pokret }\end{array}$ & $\begin{array}{c}\text { Izborni } \\
\text { apstinenti }\end{array}$ \\
\hline Društveni konzervativizam & $0,141^{* * *}$ & $0,104^{* *}$ & $-0,031$ \\
\hline & $(0,042)$ & $(0,051)$ & $(0,038)$ \\
\hline Autoritarnost & 0,004 & $-0,010$ & 0,030 \\
\hline & $(0,040)$ & $(0,049)$ & $(0,039)$ \\
\hline Populizam & $-0,103^{* *}$ & 0,042 & 0,066 \\
\hline & $(0,052)$ & $(0,069)$ & $(0,052)$ \\
\hline Ekonomski liberalizam & 0,007 & $-0,014$ & $-0,002$ \\
\hline & $(0,031)$ & $(0,038)$ & $(0,031)$ \\
\hline Religioznost & $0,190^{* *}$ & 0,080 & 0,054 \\
\hline & $(0,085)$ & $(0,109)$ & $(0,091)$ \\
\hline Suverenizam & 0,092 & 0,107 & $0,149^{* *}$ \\
\hline & $(0,066)$ & $(0,082)$ & $(0,065)$ \\
\hline Demokratska participacija & $-0,099$ & $-0,034$ & $-0,016$ \\
\hline & $(0,067)$ & $(0,084)$ & $(0,067)$ \\
\hline Dob & $-0,009$ & $-0,035^{* * *}$ & $-0,021^{* *}$ \\
\hline & $(0,009)$ & $(0,012)$ & $(0,009)$ \\
\hline Pobačaj & $-0,534$ & $-1,609^{* * *}$ & $-0,930^{* *}$ \\
\hline & $(0,392)$ & $(0,441)$ & $(0,395)$ \\
\hline Vjeronauk & $1,271^{* * *}$ & 0,140 & $0,651^{*}$ \\
\hline & $(0,320)$ & $(0,418)$ & $(0,343)$ \\
\hline Privatni sektor & $-0,166$ & $-0,294$ & 0,280 \\
\hline & $(0,281)$ & $(0,354)$ & $(0,283)$ \\
\hline NOB & $-1,047^{\star * *}$ & $-1,409^{* * *}$ & $-0,447$ \\
\hline & $(0,348)$ & $(0,531)$ & $(0,302)$ \\
\hline $\mathrm{NDH}$ & $0,802^{* *}$ & $1,097^{* * *}$ & 0,597 \\
\hline & $(0,370)$ & $(0,422)$ & $(0,393)$ \\
\hline Domovinski rat & $0,718^{* * *}$ & $0,675^{* *}$ & $-0,093$ \\
\hline & $(0,273)$ & $(0,341)$ & $(0,280)$ \\
\hline Konstanta & $-1,334$ & $-0,952$ & $-0,604$ \\
\hline & $(1,280)$ & $(1,647)$ & $(1,281)$ \\
\hline $\mathrm{N}$ & & & 856 \\
\hline Nagelkerkeov pseudo $\mathrm{R}^{2}$ & & & 0,375 \\
\hline Log-vjerodostojnost predlož & & & $-539,450$ \\
\hline Log-vjerodostojnost nultog $\mathrm{r}$ & & & $-644,230$ \\
\hline
\end{tabular}

${ }^{\star} \mathrm{p}<0,1 ;{ }^{* *} \mathrm{p}<0,05 ;{ }^{* * *} \mathrm{p}<0,01$

Napomena: referentna kategorija je "Restart koalicija". 
Tablica 4. Regresijski model 3.

\begin{tabular}{|c|c|c|c|}
\hline & \multicolumn{3}{|c|}{ Neovisne varijable } \\
\hline & HDZ & $\begin{array}{l}\text { Restart } \\
\text { koalicija }\end{array}$ & $\begin{array}{c}\text { Izborni } \\
\text { apstinenti }\end{array}$ \\
\hline \multirow[t]{2}{*}{ Društveni konzervativizam } & 0,037 & $-0,104^{* *}$ & $-0,135^{* * *}$ \\
\hline & $(0,052)$ & $(0,051)$ & $(0,052)$ \\
\hline \multirow[t]{2}{*}{ Autoritarnost } & 0,013 & 0,010 & 0,040 \\
\hline & $(0,049)$ & $(0,049)$ & $(0,050)$ \\
\hline \multirow[t]{2}{*}{ Populizam } & $-0,145^{* *}$ & $-0,042$ & 0,025 \\
\hline & $(0,069)$ & $(0,069)$ & $(0,072)$ \\
\hline \multirow[t]{2}{*}{ Ekonomski liberalizam } & 0,021 & 0,014 & 0,011 \\
\hline & $(0,037)$ & $(0,038)$ & $(0,039)$ \\
\hline \multirow[t]{2}{*}{ Religioznost } & 0,110 & $-0,080$ & $-0,026$ \\
\hline & $(0,102)$ & $(0,109)$ & $(0,111)$ \\
\hline \multirow[t]{2}{*}{ Suverenizam } & $-0,015$ & $-0,107$ & 0,042 \\
\hline & $(0,082)$ & $(0,082)$ & $(0,086)$ \\
\hline \multirow[t]{2}{*}{ Demokratska participacija } & $-0,065$ & 0,034 & 0,017 \\
\hline & $(0,080)$ & $(0,084)$ & $(0,085)$ \\
\hline \multirow[t]{2}{*}{ Dob } & $0,026^{* *}$ & $0,035^{* * *}$ & 0,014 \\
\hline & $(0,012)$ & $(0,012)$ & $(0,012)$ \\
\hline \multirow[t]{2}{*}{ Pobačaj } & $1,074^{* * *}$ & $1,609^{* * *}$ & $0,679^{*}$ \\
\hline & $(0,390)$ & $(0,441)$ & $(0,409)$ \\
\hline \multirow[t]{2}{*}{ Vjeronauk } & $1,131^{* * *}$ & $-0,140$ & 0,510 \\
\hline & $(0,378)$ & $(0,418)$ & $(0,407)$ \\
\hline \multirow[t]{2}{*}{ Privatni sektor } & 0,128 & 0,294 & 0,574 \\
\hline & $(0,344)$ & $(0,354)$ & $(0,368)$ \\
\hline \multirow[t]{2}{*}{ NOB } & 0,362 & $1,409^{* * *}$ & $0,962^{*}$ \\
\hline & $(0,574)$ & $(0,531)$ & $(0,555)$ \\
\hline \multirow[t]{2}{*}{$\mathrm{NDH}$} & $-0,295$ & $-1,097^{* * *}$ & $-0,500$ \\
\hline & $(0,367)$ & $(0,422)$ & $(0,404)$ \\
\hline \multirow[t]{2}{*}{ Domovinski rat } & 0,042 & $-0,675^{* *}$ & $-0,768^{* *}$ \\
\hline & $(0,334)$ & $(0,341)$ & $(0,353)$ \\
\hline \multirow[t]{2}{*}{ Konstanta } & $-0,382$ & 0,952 & 0,348 \\
\hline & $(1,614)$ & $(1,647)$ & $(1,690)$ \\
\hline $\mathrm{N}$ & & & 856 \\
\hline Nagelkerkeov pseudo $\mathrm{R}^{2}$ & & & 0,375 \\
\hline Log-vjerodostojnost predloženog modela & & & $-539,450$ \\
\hline Log-vjerodostojnost nultog modela & & & $-644,230$ \\
\hline
\end{tabular}

${ }^{\star} \mathrm{p}<0,1 ;{ }^{* *} \mathrm{p}<0,05 ;{ }^{* * *} \mathrm{p}<0,01$

Napomena: referentna kategorija je "Domovinski pokret". 
Tablica 5. Regresijski model 4.

\begin{tabular}{|c|c|c|c|}
\hline & \multicolumn{3}{|c|}{ Neovisne varijable } \\
\hline & HDZ & $\begin{array}{l}\text { Restart } \\
\text { koalicija }\end{array}$ & $\begin{array}{c}\text { Domovinski } \\
\text { pokret }\end{array}$ \\
\hline \multirow[t]{2}{*}{ Društveni konzervativizam } & $0,172^{* * *}$ & 0,031 & $0,135^{* * *}$ \\
\hline & $(0,044)$ & $(0,038)$ & $(0,052)$ \\
\hline \multirow[t]{2}{*}{ Autoritarnost } & $-0,027$ & $-0,030$ & $-0,040$ \\
\hline & $(0,042)$ & $(0,039)$ & $(0,050)$ \\
\hline \multirow[t]{2}{*}{ Populizam } & $-0,170^{* * *}$ & $-0,067$ & $-0,025$ \\
\hline & $(0,057)$ & $(0,052)$ & $(0,072)$ \\
\hline \multirow[t]{2}{*}{ Ekonomski liberalizam } & 0,010 & 0,002 & $-0,011$ \\
\hline & $(0,032)$ & $(0,031)$ & $(0,039)$ \\
\hline \multirow[t]{2}{*}{ Religioznost } & 0,136 & $-0,054$ & 0,026 \\
\hline & $(0,090)$ & $(0,091)$ & $(0,111)$ \\
\hline \multirow[t]{2}{*}{ Suverenizam } & $-0,057$ & $-0,149^{* *}$ & $-0,042$ \\
\hline & $(0,072)$ & $(0,065)$ & $(0,086)$ \\
\hline \multirow[t]{2}{*}{ Demokratska participacija } & $-0,082$ & 0,016 & $-0,017$ \\
\hline & $(0,070)$ & $(0,067)$ & $(0,085)$ \\
\hline \multirow[t]{2}{*}{ Dob } & 0,012 & $0,021^{* *}$ & $-0,014$ \\
\hline & $(0,010)$ & $(0,009)$ & $(0,012)$ \\
\hline \multirow[t]{2}{*}{ Pobačaj } & 0,396 & $0,930^{* *}$ & $-0,679^{*}$ \\
\hline & $(0,356)$ & $(0,395)$ & $(0,409)$ \\
\hline \multirow[t]{2}{*}{ Vjeronauk } & $0,620^{*}$ & $-0,651^{*}$ & $-0,510$ \\
\hline & $(0,321)$ & $(0,343)$ & $(0,407)$ \\
\hline \multirow[t]{2}{*}{ Privatni sektor } & $-0,446$ & $-0,280$ & $-0,574$ \\
\hline & $(0,304)$ & $(0,283)$ & $(0,368)$ \\
\hline \multirow[t]{2}{*}{ NOB } & $-0,601$ & 0,447 & $-0,962^{*}$ \\
\hline & $(0,390)$ & $(0,302)$ & $(0,555$ \\
\hline \multirow[t]{2}{*}{$\mathrm{NDH}$} & 0,206 & $-0,597$ & 0,500 \\
\hline & $(0,353)$ & $(0,393)$ & $(0,404$ \\
\hline \multirow[t]{2}{*}{ Domovinski rat } & $0,810^{* * *}$ & 0,093 & $0,768^{* *}$ \\
\hline & $(0,292)$ & $(0,280)$ & $(0,353)$ \\
\hline \multirow[t]{2}{*}{ Konstanta } & $-0,729$ & 0,604 & $-0,348$ \\
\hline & $(1,355)$ & $(1,281)$ & $(1,690)$ \\
\hline $\mathrm{N}$ & & & 856 \\
\hline Nagelkerkeov pseudo $\mathrm{R}^{2}$ & & & 0,375 \\
\hline Log-vjerodostojnost predloženog modela & & & $-539,450$ \\
\hline Log-vjerodostojnost nultog modela & & & $-644,230$ \\
\hline
\end{tabular}

${ }^{\star} \mathrm{p}<0,1 ;{ }^{* *} \mathrm{p}<0,05 ;{ }^{* * *} \mathrm{p}<0,01$

Napomena: referentna kategorija je "Izborni apstinenti". 


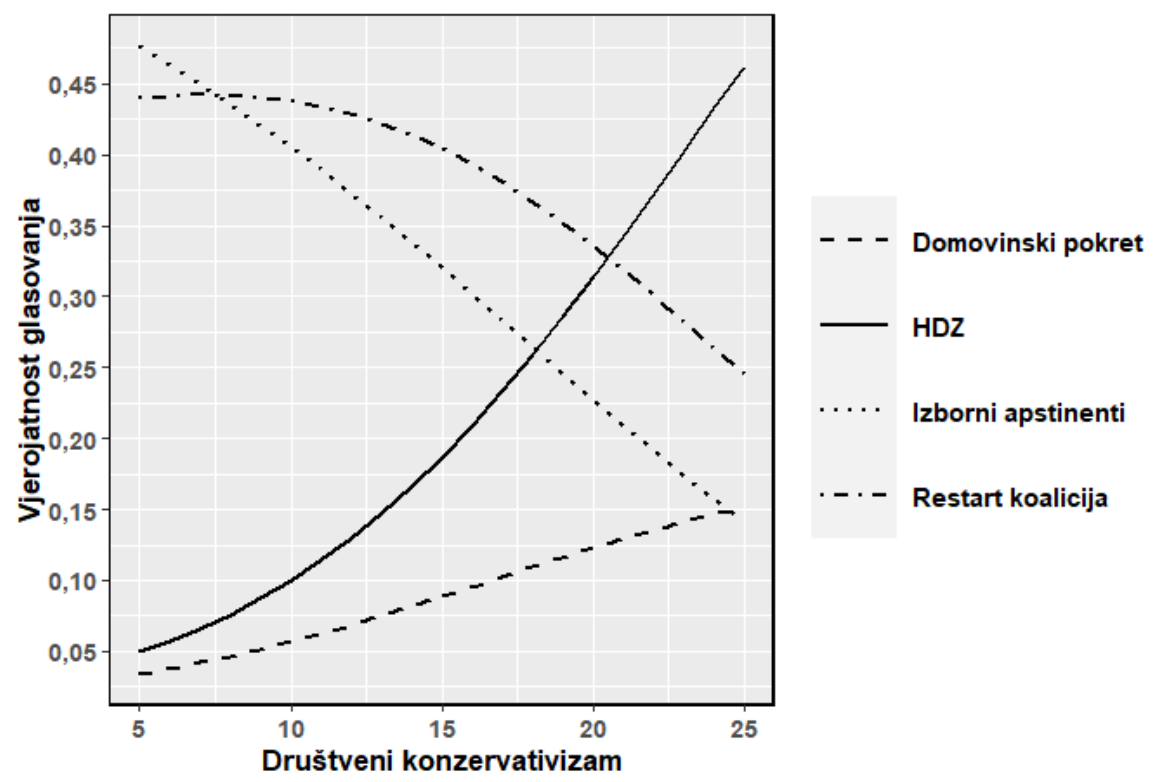

Slika 2. Društveni konzervativizam i vjerojatnost glasovanja

Iz slike 1. može se također zaključiti kako se u uzorku ističu ispitanici koji rijetko pohađaju vjerske obrede ("običajni" ili "godišnji" vjernici), što se uvelike poklapa $s$ rezultatima recentnih istraživanja koja su proveli sociolozi religije (Nikodem i Zrinščak 2019: 377). Zanimljivo je primijetiti i to da je velik dio ispitanika grupiran na najvišim vrijednostima varijable koja mjeri stav o potrebi veće mogućnosti demokratske participacije.

Takvi nalazi na makrorazini ne bi trebali čuditi istraživače stavova u hrvatskom društvu, ali je važno eksplicitno prezentirati te uvide kako bi se bolje sagledali nalazi u nastavku istraživanja.

Tablice 2-5 pokazuju da predloženi regresijski model bolje objašnjava promatrani ishod nego nulti model (-2LL predloženog modela manji je od $-2 L L$ vrijednosti nultog modela). Uz to, Nagelkerkeov izračun pseudo $\mathrm{R}^{2}$ daje vrijednost od 0,375 , što svjedoči o dovoljno dobroj prilagodbi modela. Statistič- ki značajni koeficijenti utvrđeni su za varijable društvenog konzervativizma, populizma, suverenizma, religioznosti, dobi, slobodnog odlučivanja o pobačaju, školskog vjeronauka, obiteljskog naslijeđa NOB-a te obiteljskog naslijeđa Domovinskog rata. Drugim riječima, osim ekonomskih (ekonomski liberalizam) i socijalno-ekonomskih (privatni sektor) varijabla te ljestvica autoritarnosti i demokratske participacije, svi ostali prediktori u predloženom modelu pokazali su se statistički značajnima.

Analiza marginalnih efekata za varijablu društvenog konzervativizma (slika 2) pokazuje kako s većim vrijednostima na toj ljestvici raste vjerojatnost glasovanja za HDZ i Domovinski pokret, a pada za Restart koaliciju ili za opciju neizlaska na izbore (izborni apstinenti), s time da je utjecaj društvenog konzervativizma posebice izražen u slučaju HDZ-a. Premda se na temelju Čularova i Šalajeva rada (2019) moglo očekivati da bi autoritarnost mogla (ponovno) biti dobar 


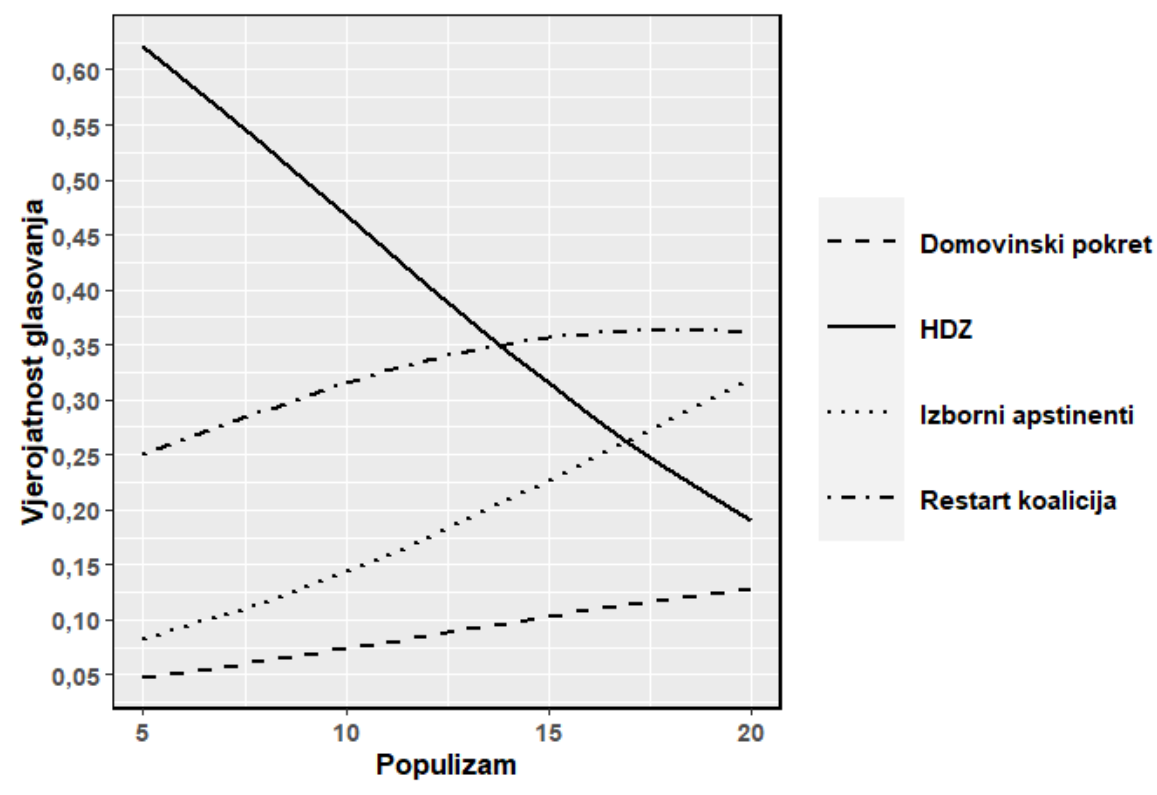

Slika 3. Populizam i vjerojatnost glasovanja

prediktor glasovanja za stranke desno od centra, ta varijabla nije pokazala statistički značajan učinak u predloženom modelu. Uzevši oba nalaza u obzir, očito je da korištena ljestvica dobro bilježi razlike u razinama društvenog konzervativizma te, očekivano, više vrijednosti i veće vjerojatnosti glasovanja, povezane $s$ višim vrijednostima, vezuje za stranke desno od centra.

Izračun marginalnih efekata za novu ljestvicu populizma (slika 3) pokazuje zanimljivu dinamiku kod HDZ-a, gdje $s$ rastom vrijednosti na ljestvici populizma prilično oštro pada vjerojatnost glasovanja za tu stranku. Nasuprot tome, za izborne apstinente, a u mnogo manjoj mjeri i za Domovinski pokret, može se ustvrditi suprotno, odnosno da s većim vrijednostima na ljestvici raste vjerojatnost toga ishoda na ovisnoj varijabli. $S$ obzirom na mnoge democentrične, ali protuelitističke izjave čelnika potonje političke grupacije, bila je očekivana pozitivna sprega viših vrijednosti po- pulizma i veće vjerojatnosti glasovanja za Domovinski pokret, ali se pokazalo da ona ipak nije toliko izražena koliko se možda očekivalo. Povezanost razine populizma i vjerojatnosti neizlaska na izbore (odnosno ishoda "izborni apstinenti") dobro se uklapa u prijašnja istraživanja koja su pokazala kako su izborni apstinenti, u usporedbi s biračima etabliranih ("starih") i izazivačkih ("novih") stranaka, politički, ali i socijalno-ekonomski isključeni (Henjak 2017: 98-99). Osjećaj isključenosti lako se pretače u protuelitističke stavove. koji su jedna od triju glavnih sastavnica populizma mjerenoga ovom ljestvicom. U donošenju konačna suda o negativnoj povezanosti povećanja vrijednosti na ljestvici populizma i vjerojatnosti glasovanja za HDZ-a treba ipak biti oprezan s obzirom na to da taj nalaz možda ne znači nužno da ispitanici koji preferiraju HDZ doista imaju slabije populističke stavove nego, primjerice, dvije čestice na toj ljestvici (v. tablicu 12) glase: "Vlada radi iskljucivo u korist nekoliko krupnih 


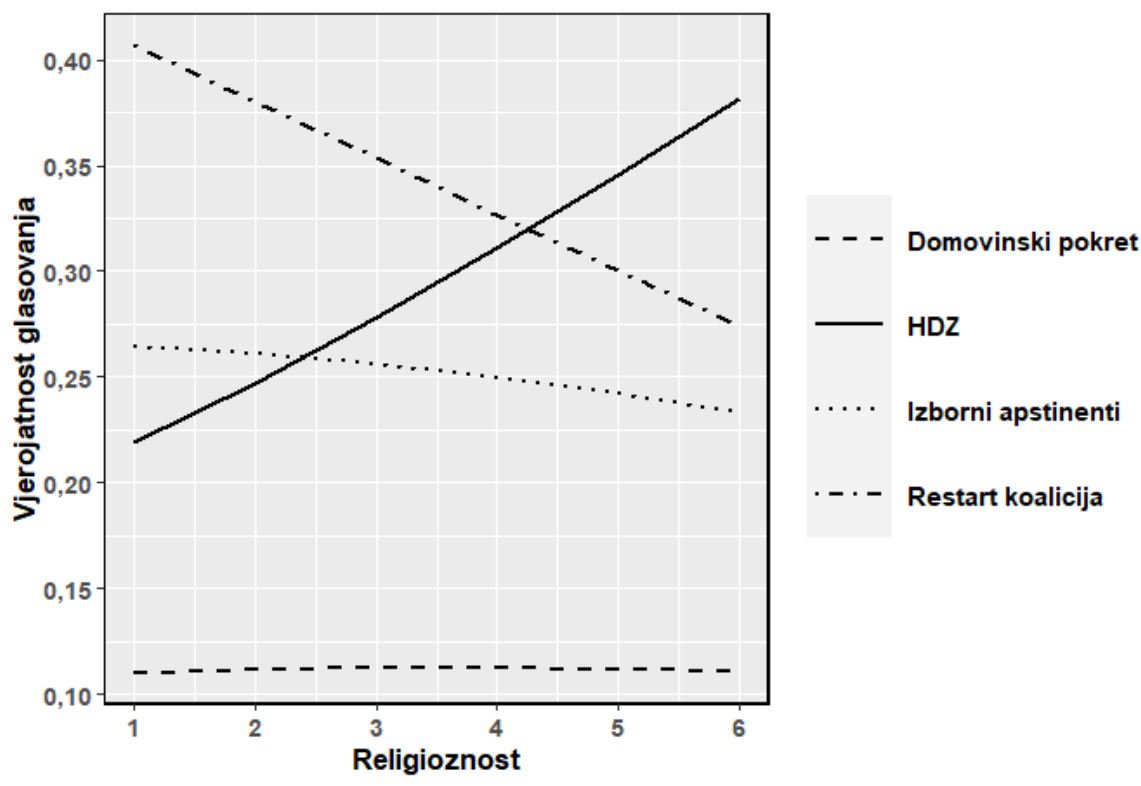

Slika 4. Religioznost i vjerojatnost glasovanja

interesnih grupa koje brinu samo o sebi" i "Malo tko od ljudi u vladi je pokvaren". Premda, prema zamisli autora, ljestvica označava općenito državnu (izvršnu) vlast (government), riječ vlada dio ispitanika može protumačiti kao vladu u užem smislu (cabinet). Stoga ispitanici koji preferiraju premijerovu stranku (HDZ) u trenutku provođenja anketa zasigurno nisu pokazali visok stupanj suglasnosti s tim izjavama te su posljedično imali niže vrijednosti na ljestvici populizma.

Kao što je vidljivo iz tablica 2-5, varijabla ekonomskog liberalizma nije se pokazala statistički značajnom. Ostaje otvorenim pitanje jesu li čestice iz ankete koje su odabrane za tu mjeru - stupanj suglasnosti $s$ tržišnim rješenjima $u$ obrazovanju, stambenoj politici i politici zapošljavanja (v. tablicu 9) - odgovarajuće zahvatile razlike u ekonomskim stavovima ispitanika. Izostanak statistički značajnog rezultata dobro se nadovezuje na sva prethodna istraživanja koja su detektirala slabe ili nikakve učinke ekonomskih stavova na biračke preferencije. Stranačka identifikacija naknadno determinira stavove o ekonomskim temama.

Izračun marginalnih efekata za varijablu religioznosti (slika 4) potvrđuje prijašnja istraživanja (npr. Raos 2019: 23-24) koja su pokazala kako je upravo religioznost, mjerena učestalošću odlaska na vjerske obrede, ponajbolji prediktor glasovanja za HDZ. Slika 4. ilustrira kako $s$ učestalošću pohađanja vjerskih obrade pada vjerojatnost glasovanja za koaliciju lijevog centra, a raste za HDZ. No zanimljivo je da religioznost uopće nije prediktor glasovanja za Domovinski pokret, odnosno s pomakom na ljestvici religioznosti ne detektiramo bilo kakvu promjenu u vjerojatnosti glasovanja za skupinu stranaka okupljenih oko Miroslava Škore.

Analiza marginalnih efekata za varijablu dobi pokazuje vrlo snažan efekt za Restart koaliciju - s porastom životne 


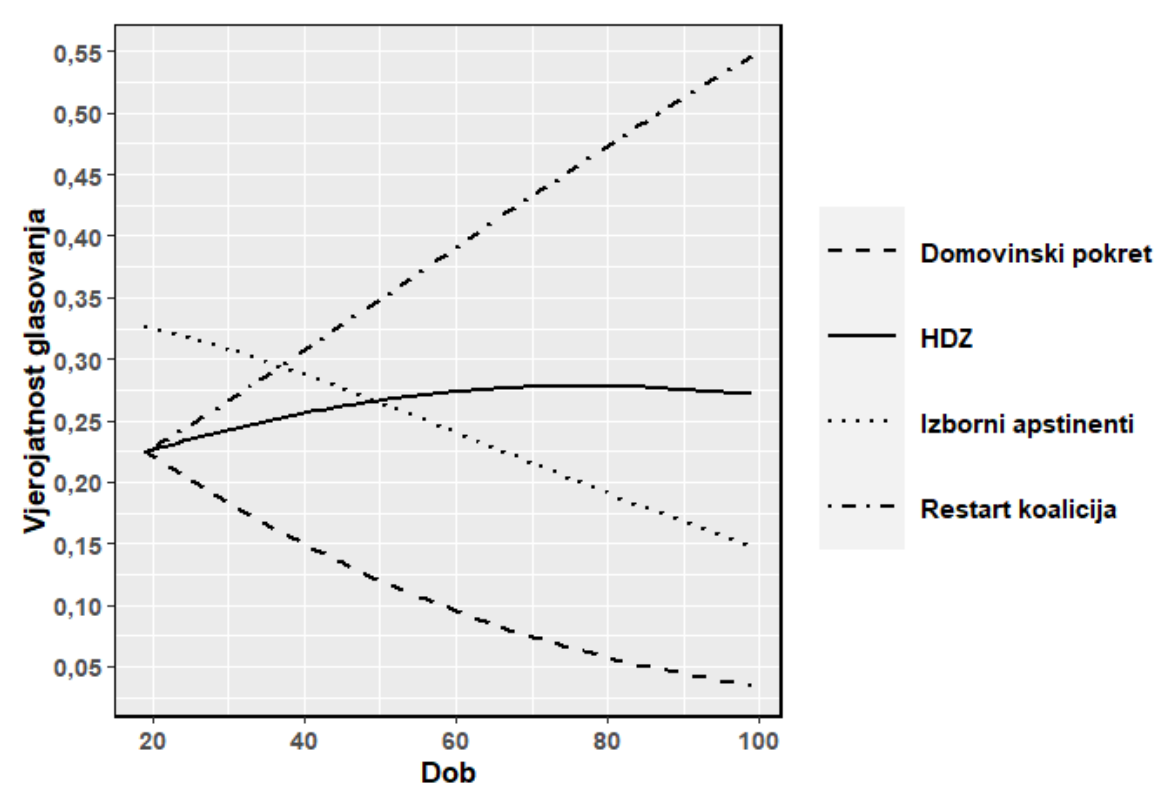

Slika 5. Dob i vjerojatnost glasovanja

dobi snažno raste vjerojatnost glasovanja za tu političku opciju. Nasuprot tome, birači mlađe životne dobi više glasuju za Domovinski pokret, ali su i češći izborni apstinenti, premda je efekt slabiji. Taj se nalaz uklapa u argumentaciju prema kojoj nove stranke privlače mlađe birače, ali i u uvid da mladi manje sudjeluju u izborima od ostatka populacije (usp. Henjak 2018: 403).

Kod varijable suverenizma (slika 6) možemo vidjeti kako se s većim vrijednostima smanjivala vjerojatnost glasovanja za Restart koaliciju, a rasla vjerojatnost da će ispitanici bili izborni apstinenti, s time da je za potonju skupinu taj efekt manje izražen. Nasuprot tome, kod HDZ-a i Domovinskog pokreta ne može se govoriti o nikakvoj svezi kretanja na toj ljestvici i vjerojatnosti glasovanja. Zanimljivo je da s povećanjem stupnja suglasnosti s izjavom da bi trebalo manje odluka donositi na europskoj razini raste vjerojatnost da ispitanici neće glasovati, a ne da će glasovati za listu koja se sama predstavlja kao suverenistička (Domovinski pokret). To se može tumačiti i kao pokazatelj da u Domovinskom pokretu kao novoj stranci koja privlači heterogeno biračko tijelo - poput birača Živog zida, ali i Mosta nezavisnih lista, makar u prvim godinama djelovanja postoji raskorak između stavova birača ili makar simpatizera i vodstva stranke i njezina proklamiranoga političkog sadržaja.

Demokratska participacija - za koju se zbog prominentnosti te teme posljednjih godina, ali i zbog činjenice da neki izborni akteri, poglavito Domovinski pokret i Most nezavisnih lista, često koriste argumente da su institucije otuđene od građana ze da postoje demokratski deficit i potreba za više (referendumske) demokracije, pa se očekivalo da bi mogla biti dobar prediktor biračkih preferencija - nije se pokazala kao statistički značajna varijabla u predloženom modelu. 


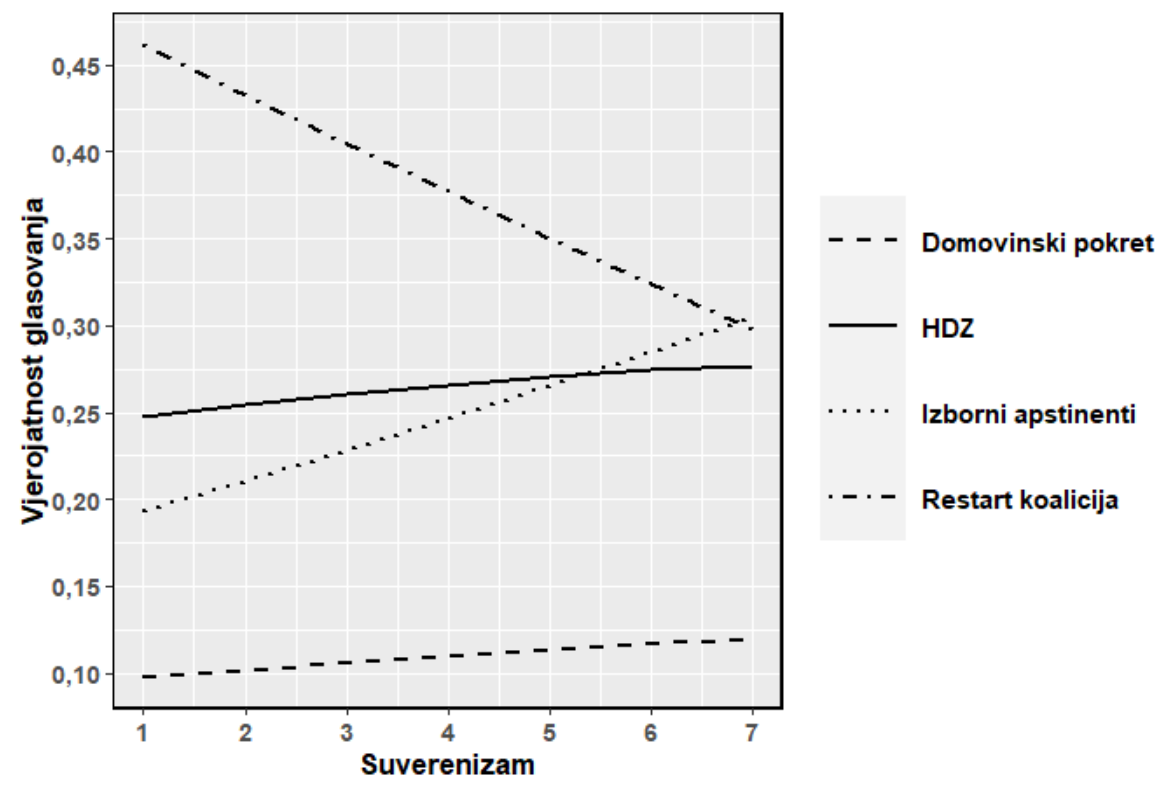

Slika 6. Suverenizam i vjerojatnost glasovanja

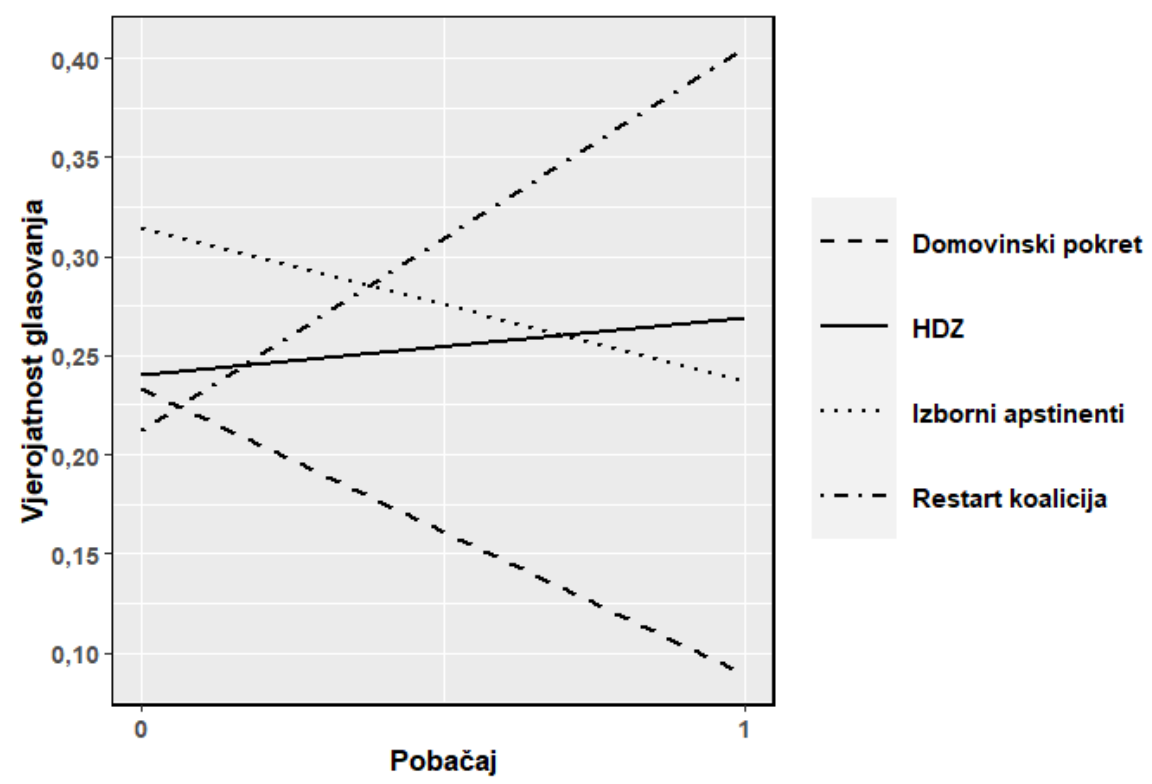

Slika 7. Pobačaj i vjerojatnost glasovanja

Pitanje zakonskog uređenja prekida vinskog pokreta i Mosta nezavisnih lista, trudnoće tijekom izborne kampanje $\mathrm{u}$ dok su se istaknuti članovi etabliranih kasno proljeće i rano ljeto 2020. snažno stranaka lijevo od centra (Restart koalisu potencirali istaknuti članovi Domo- cija) i novi akteri na ljevici (Možemo!) 


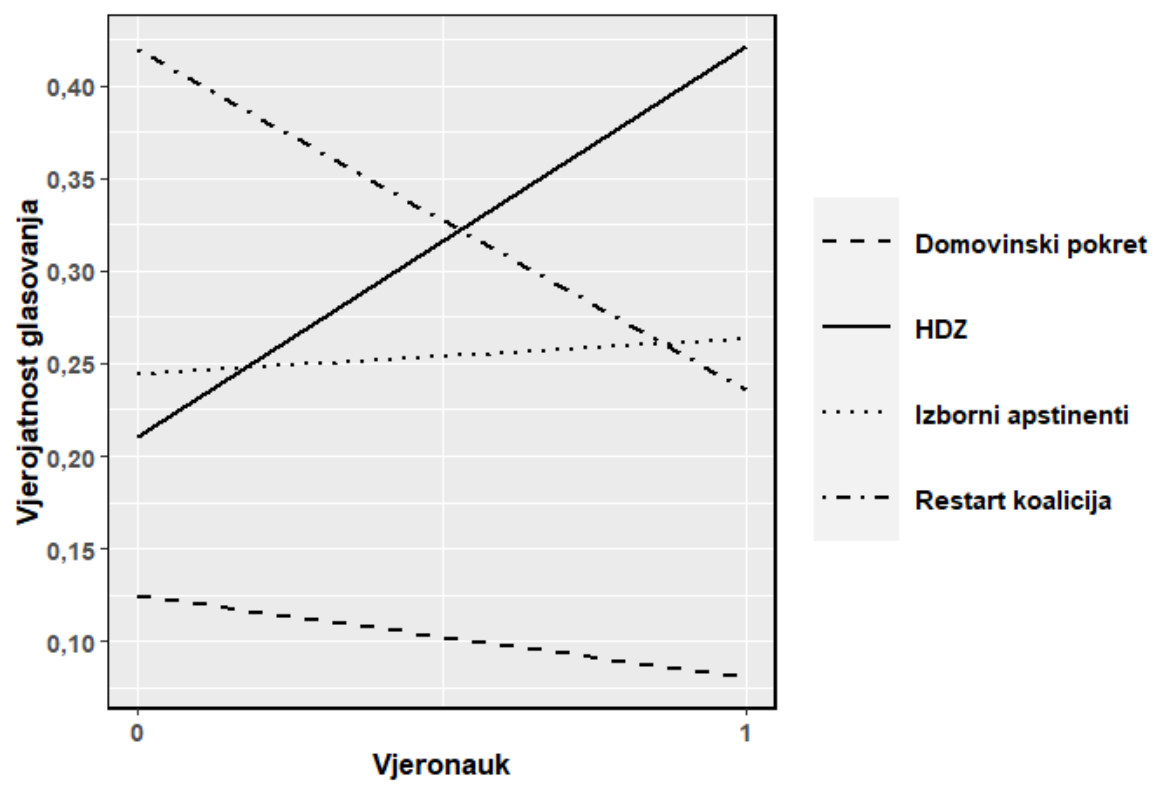

Slika 8. Vjeronauk i vjerojatnost glasovanja

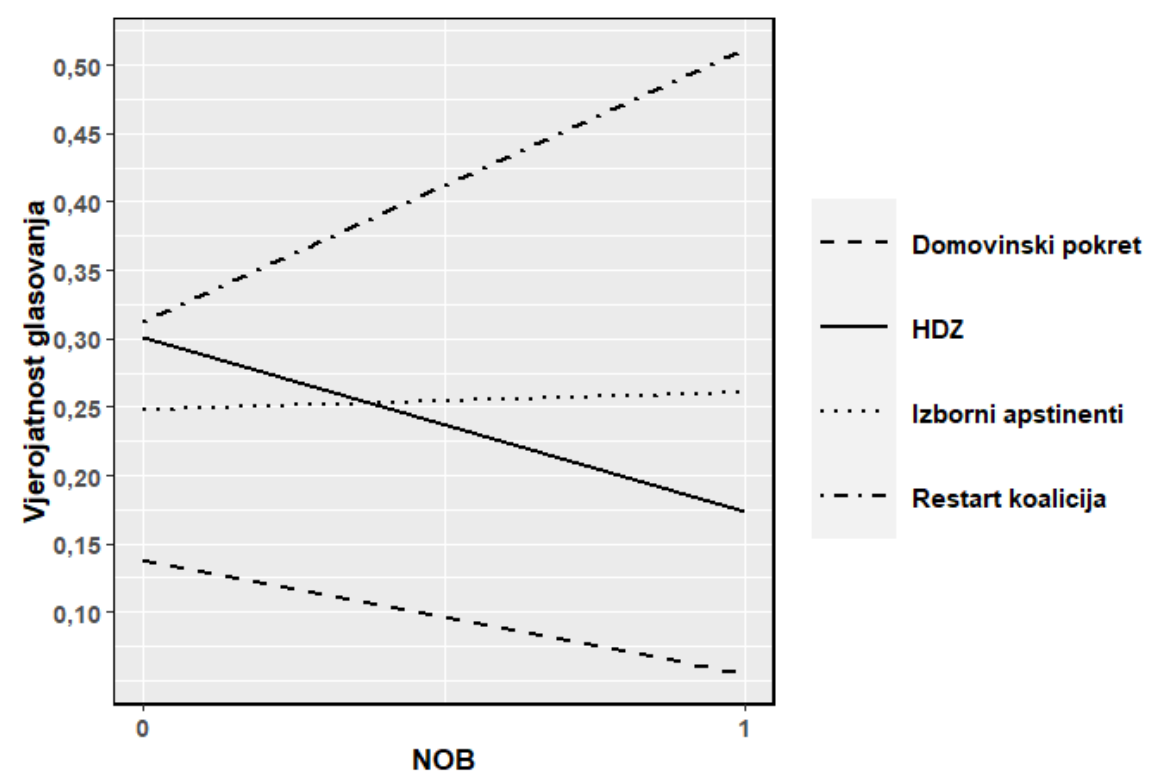

Slika 9. Naslijeđe NOB-a i vjerojatnost glasovanja

snažno zauzimali za slobodno odlučiva- je zatečeno stanje, istodobno ponavljanje žena o prekidu trudnoće i zakonsku jući načelno zauzimanje za zaštitu života dostupnost pobačaja. HDZ se pritom dr- od začeća. Detektiran je snažan pozitižao prilično postrance, odnosno branio van efekt glasovanja za Restart koaliciju, 


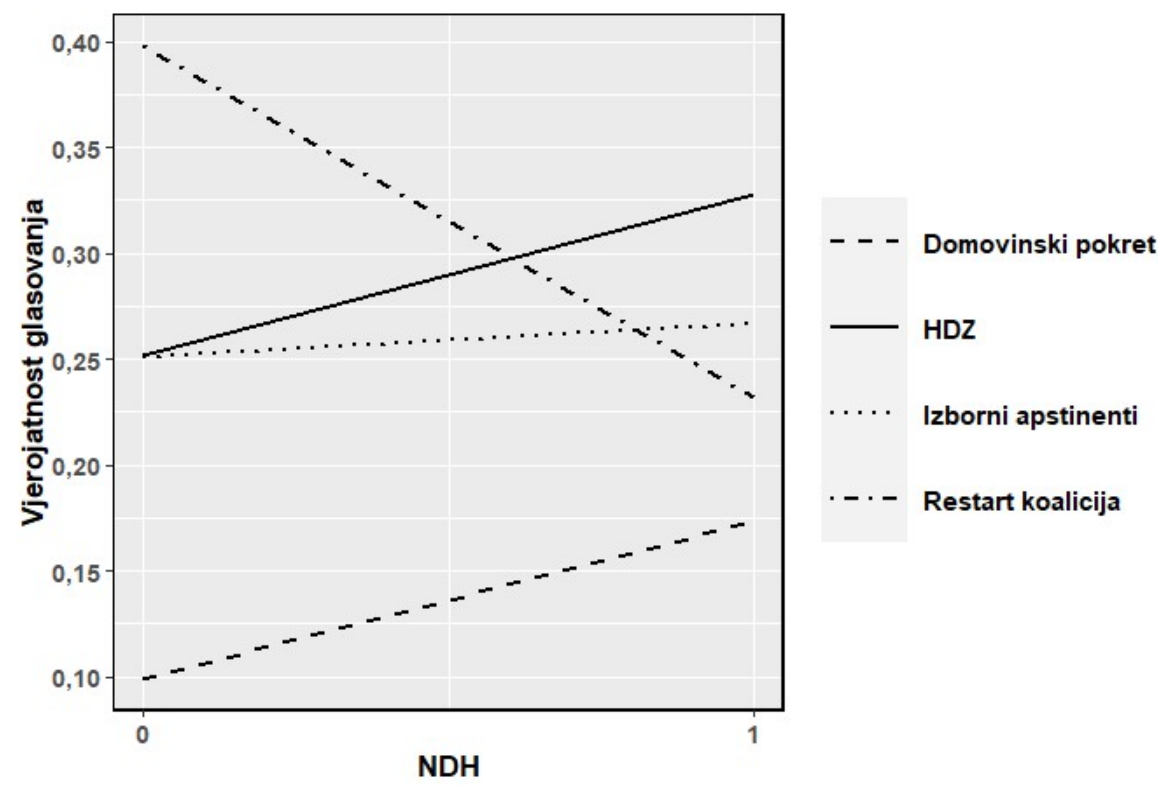

Slika 10. Naslijeđe NDH i vjerojatnost glasovanja

a negativan za Domovinski pokret, dok kod HDZ-a stav o tome pitanju gotovo uopće nije utjecao na vjerojatnost glasovanja za tu stranku (slika 7).

Podrška školskom vjeronauku ističe se kao izrazito snažan pozitivan prediktor glasovanja za HDZ i negativan za Restart koaliciju. Treba istaći kako pozitivan stav o izvođenju vjeronauka u školi ne daje gotovo nikakav efekt glede pitanja vjerojatnosti glasovanja za Domovinski pokret. Pitanja slobodnog odlučivanja o prekidu trudnoće i školskog vjeronauka koncepcijski su povezana $s$ razinom religioznosti te se stoga potvrđuju kao dobri dodatni indikatori kulturno-vrijednosnog rascjepa.

Dihotomne varijable koje mjere odnos prema prošlosti, odnosno obiteljskim naslijeđima Drugoga svjetskog rata $\mathrm{i}$ Domovinskog rata, u izračunima marginalnih efekata (slike 9. i 10) pokazuju kako obiteljsko naslijeđe partizanskog pokreta snažno povećava vjerojatnost glasovanja za lijevi centar, dok uz mno- go manji efekt smanjuje vjerojatnost glasovanja za HDZ ili Domovinski pokret. Jednako tako, obiteljsko naslijeđe NDH snažan je negativni prediktor glasovanja za Restart koaliciju, dok mnogo slabije povećava vjerojatnost glasovanja za HDZ ili Domovinski pokret. Drugim riječima, odnos prema prošlosti još je uvijek vrlo dobar prediktor biračkih preferencija, s time da ima snažniji utjecaj na birače koji preferiraju opcije lijevo od centra.

Naposljetku, obiteljsko naslijeđe Domovinskog rata, varijabla koja je kao novost uvedena u ovo istraživanje, snažno povećava vjerojatnost glasovanja za HDZ te, u mnogo manjoj mjeri, za Domovinski pokret (slika 11). Obratno, $s$ braniteljskim statusom ispitanika $\mathrm{i} / \mathrm{ili}$ njegovih ili njezinih ukućana značajno pada vjerojatnost da će netko glasovati za Restart koaliciju ili apstinirati od izbora. Ti su nalazi potvrdili očekivanje da bi braniteljski status ispitanika ili njihovih obitelji mogao biti dobar pre- 


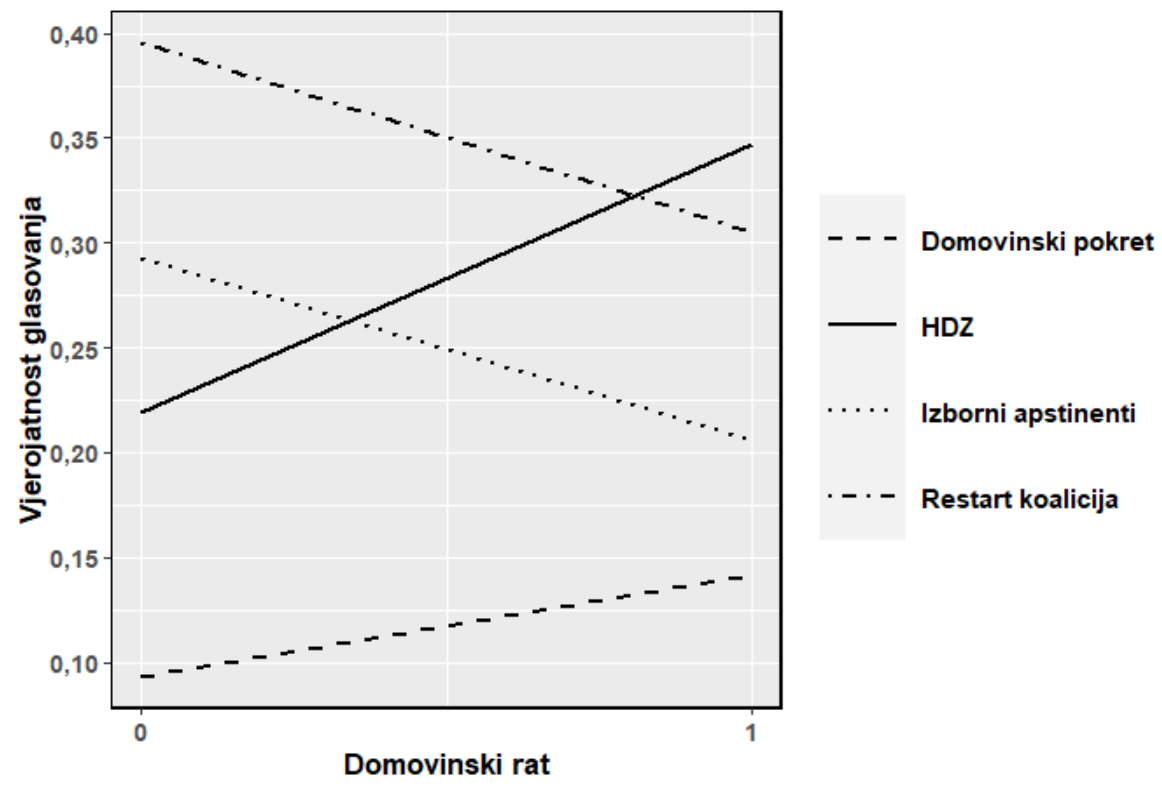

Slika 11. Naslijeđe Domovinskog rata i vjerojatnost glasovanja

diktor glasovanja za stranke desno od centra, posebice one koje ističu sjećanje na Domovinski rat i nastoje održavati posebno blizak odnos s braniteljskom populacijom.

\section{Zaključak}

U ovome istraživanju nastojalo se utvrditi jesu li biračke preferencije u Hrvatskoj još uvijek stabilno strukturirane uzduž kulturnog rascjepa, koji je utvrđen poglavito na temelju odnosa prema religiji, i povijesnoga društvenog rascjepa, koji je ukorijenjen u vrednovanju naslijeđa Drugoga svjetskog rata i Domovinskog rata, ili se može govoriti i o pojavi ekonomske dimenzije koja determinira ponašanje birača, kao i rascjepa povezanih s pitanjima suverenizma i zahtjeva za većom demokratskom participacijom. Predloženi model multinominalne logističke regresije dao je statistički značajne koeficijente za varijable društveni konzervativizam, populizam, pobačaj, vjeronauk, dob, NOB, NDH, Domovinski rat i suverenizam. Najveći koeficijenti dobiveni su za varijable pobačaj, vjeronauk, NOB i Domovinski rat, što potvrđuje prethodne nalaze koji govore kako se biračke preferencije $\mathrm{u}$ hrvatskom društvu temelje na kulturno-vrijednosnima i povijesno-identitetskim rascjepima. Unatoč uvođenju novih mjerila ekonomskih stavova (varijabla ekonomski liberalizam), kao i kontrastiranja birača s obzirom na zaposlenje u privatnome ili javnom sektoru, nije utvrđeno da se pojavio nov rascjep ukorijenjen u razlikama u ekonomskim stavovima birača. Također, opreka između pobornika i osporavatelja nacionalnoga, odnosno nadnacionalnog odlučivanja i kreiranja vanjske politike, dala je tek slabe razlike među biračima pojedinih stranaka, dok se zahtjev za većom razinom suodlučivanja građana (demokratska participacija) nije potvrdio kao osnova za otvaranje novoga društvenog rascjepa. Zanimljivi rezultati dobiveni su kod varijable populizam, gdje je analiza marginalnih efekata pokazala kako se s ra- 
stom vrijednosti na ljestvici populizma snažno smanjuje vjerojatnost glasovanja za HDZ. To se može tumačiti i kao manja sklonost protuelitizmu, jednoj od sastavnica te ljestvice, kod ispitanika koji podržavaju HDZ. Buduća istraživanja koja budu koristila tu ljestvicu na anketnim podacima za izbore 2020. mogla bi ponuditi dodatna objašnjenja takva nalaza. Kada se promotre razlike između birača HDZ-a i Domovinskog pokreta, pokazuje se kako će pristaše Miroslava Škore vjerojatnije biti protiv slobodnog odlučivanja o prekidu trudnoće, da su nešto skloniji populističnim stavovima, da je manje vjerojatno kako imaju braniteljski status i da slabije podržavaju školski vjeronauk. Stoga se može reći kako religioznost, iskustvo Domovinskog rata i više vrijednosti društvenog konzervativizma izdvajaju HDZ-ove birače od svih ostalih skupina, pa i skupine birača Domovinskog pokreta, dok se negati- van stav prema slobodnom odlučivanju o prekidu trudnoće iskače kao posebno dobar prediktor glasovanja za stranku Miroslava Škore. Birači te stranke dijele dobna obilježja - mlađi ispitanici pokazuju veću vjerojatnost da se odluče za tu opciju - s izbornim apstinentima, kao i sklonost populističkim stavovima.

Zaključno se može kazati da je analiza na temelju podataka dobivenih anketom provedenom uoči izbora 2020. potvrdila kako birače HDZ-a i birače lijevoga centra, predvođenoga SDP-om, još uvijek ponajviše dijele stavovi o prošlosti i stupanj religioznosti, dok se Domovinski pokret, uz određene sličnosti s HDZ-om kao glavnom strankom desno od centra, nastavlja na trend prethodnih, slabije vrijednosno određenih novih stranaka koje privlače mlađe birače i građane koji imaju slična obilježja kao izborni apstinenti. 


\section{Literatura}

Adorno, Theodor W., Frenkel-Brunswik, Else, Levinson, Daniel J., Sanford, R. Nevitt. 1950. The Authoritarian Personality. New York: Harper \& Brothers.

Ančić, Branko, Baketa, Nikola, Kovačić, Marko. 2019. Exploration of Class and Political Behavior in Croatia. International Journal of Sociology. (49) 4: 264-281. https://doi.org/10.1080/00207659.2019.1634826

Bagić, Dragan. 2007. Društveni rascjepi i stranačke preferencije na izborima za Hrvatski sabor 2003. godine. Politička misao (44) 4): 93-115.

Bagić, Dragan, Kardov, Kruno. 2018. Politička participacija i stranačke preferencije ratnih veterana u Hrvatskoj. Politička misao. (55) 3: 82-103. https://doi. org/10.20901/pm.55.3.03

Bago, Mislav. 2020. Crobarometar otkriva odnos snaga mjesec dana prije izbora: HDZ ispred RESTART koalicije, Škoro treći. Dnevnik.hr. 25. svibnja 2020. https:// dnevnik.hr/vijesti/parlamentarni-izbori-2020/crobarometar-za-svibanj-hdz-navrhu-ali-im-je-restart-za-petama---606754.html

Basile, Linda, Borri, Rossella, Verzichelli, Luca. 2020. 'For whom the sovereignist Bell Tolls?' Individual determinants of support for sovereignism in ten European countries. European Politics and Society. (21) 2: 235-257. https://doi.org/10.1080/ 23745118.2019.1633035

Castanho Silva i sur. 2019. Public opinion surveys: a new measure. U: Hawkins, Kirk A., Carlin, Ryan E., Littvay, Levente, Rovira Kaltwasser, Cristóbal. (ur.). The Ideational Approach to Populism: Concept, Theory, and Analysis. Abingdon, Oxon i New York: Routledge, Francis \& Taylor Group, str. 150-177.

Čepo, Dario, Nikić Čakar, Dario. 2019. Direct democracy and the rise of political entrepreneurs: an analysis of citizens' initiatives in post-2010 Croatia. Anali $\mathrm{Hr}$ vatskog politološkog društva. (16) 1: 27-48. https://doi.org/10.20901/an.16.02

Čular, Goran. 1999. Koncept lijevog i desnog u empirijskoj političkoj znanosti: značenje, razumijevanje, struktura, sadržaj. Politička misao. (36) 1: 153-168.

Čular, Goran. 2004. Razvoj hrvatskog stranačkog sustava: četiri teze. U: Kregar, Josip, Puljiz, Vlado, Ravlić, Slaven. (ur.) Hrvatska - kako dalje? zadanosti i mogućnosti. Zagreb: Centar za demokraciju i pravo "Miko Tripalo", str. 135-150.

Čular, Goran, Šalaj, Berto. 2019. Kritički građani ili nezadovoljni autokrati? Potpora demokraciji u Hrvatskoj 1999-2018. Anali Hrvatskog politološkog društva (16) 1: 7-26. https://doi.org/10.20901/an.16.01

De Vries, Catherine E., Hobolt, Sara B. 2020. Political Entrepreneurs: The Rise of Challenger Parties in Europe. Princeton: Princeton University Press.

Dolenec, Danijela. 2012. The Absent Socioeconomic Cleavage in Croatia: a Failure of Representative Democracy? Politička misao. (49) 5: 69-88.

Henjak, Andrija. 2007. Values or Interests: Economic Determinants of Voting Behavior in the 2007 Croatian Parliamentary Elections. Politička misao. (44) 5: 71-90.

Henjak, Andrija. 2011. Stranačka identifikacija i granice stranačke mobilizacije u Hrvatskoj nakon 2000. godine. Političke perspektive. (1) 1:29-55.

Henjak, Andrija. 2017. Lojalnost, glas ili izlazak: izborna participacija i potpora novim strankama u Hrvatskoj. Anali Hrvatskog politološkog društva. (14) 1: 79-103. https://doi.org/10.20901/an.14.04 
Henjak, Andrija. 2018. Nose li parlamentarni izbori 2015. i 2016. godine promjenu političkih rascjepa u Hrvatskoj? Društvena istraživanja. (27) 3: 383-406. https:// doi.org/10.5559/di.27.3.01

Henjak, Andrija, Zakošek, Nenad, Čular, Goran. 2013. Croatia. U: Berglund, Sten, Ekman, Joakim, Deegan-Krause, Kevin, Knuten, Terje. (ur.). The Handbook of Political Change in Eastern Europe. 3. izd. Cheltenham i Northampton: Edward Elgar, str. 443-480.

Hoekstra, Rink, Vugteveen, Jorien, Warrens, Matthijs J., Kruyen, Peter M. 2019. An empirical analysis of alleged misunderstandings of coefficient alpha. International Journal of Social Research Methodology. (22) 4: 351-364. https://doi.org/10.1080/1 3645579.2018.1547523

Glaurdić, Josip, Vuković, Vuk. 2016. Voting after war: Legacy of conflict and the economy as determinants of electoral support in Croatia. Electoral Studies. (42) 1: 135-145. https://doi.org/10.1016/j.electstud.2016.02.012

Grbeša, Marijana, Šalaj, Berto. 2017. Populism in Croatia: The Curious Case of The Bridge (Most). Anali Hrvatskog politološkog društva. (14) 1: 7-30. https://doi. org/10.20901/an.14.01

Linz, Juan J., Stepan, A. 1996. Problems of Democratic Transition and Consolidation: Southern Europe, South America, and Post-Communist Europe. Baltimore: The Johns Hopkins University Press.

Nikodem, Krunoslav, Zrinščak, Siniša. 2019. Između distancirane crkvenosti i intenzivne osobne religioznosti: religijske promjene u hrvatskom društvu od 1999. do 2018. godine. Društvena istraživanja (28) 3: 371-390. https://doi.org/10.5559/ di.28.3.01

Putnick, Diane L., Bornstein, Marc H. (2016) Measurement invariance conventions an reporting: The state of the art and future directions for psychological research. Developmental Review. (41) 1: 71-90. https://doi.org/10.1016/j.dr.2016.06.004

Raos, Višeslav. 2015. Izbori 2015.: jesmo li ušli u razdoblje nestabilnosti i nepreglednosti? Političke analize. (6) 24: 3-11.

Raos, Višeslav. 2019. Ideology, Partisanship, and Change: Voter Profiles of Main Political Parties in Croatia. Politička misao. (56) 3-4: 7-28.

Šiber, Ivan. 1997. Izborne orijentacije i ideologijski sukobi tijekom Drugoga svjetskog rata. Značenje političke biografije obitelji. Politička misao. (34) 2: 104-128.

Šiber, Ivan. 1998. Autoritarna ličnost, politički svjetonazor i stranačka preferencija. Politička misao. (35) 4: 193-209. 


\section{Prilozi}

Tablica 6. Ljestvica društvenog konzervativizma

Nema društvenog napretka bez poštivanja autoriteta u obitelji, školi i državi.

Sukobi različitih interesnih skupina u našem društvu škode općem interesu države.

Treba se vratiti tradiciji i izvornim vrijednostima svoga naroda.

Hrvatskoj bi bilo bolje kad bi svi građani slijedili kršćanske moralne vrijednosti.

Države u kojima u velikoj većini živi samo jedna nacija i vjera stabilnije su od država s više nacija i vjera.

Pod izgovorom traženja ravnopravnosti, žene zapravo traže posebne povlastice.

Napomena: osjenčene su čestice isključene iz analize.

Tablica 7. Ljestvica autoritarnosti

Mišljenje većine uvijek je najbolje.

Ono što je ovoj zemlji potrebnije od zakona i političkih programa jest nekoliko hrabrih i odlučnih ljudi u koje narod može imati povjerenje.

Ne treba iznositi vlastito mišljenje, jer čovjek nikad ne zna od čega može nastradati.

Vlasti i moćnicima ne treba se zamjerati.

Ono što je mladima najpotrebnije, to su stroga disciplina, odlučnost i volja da rade i da se bore za obitelj i domovinu.

Tablica 8. Ljestvica populizma

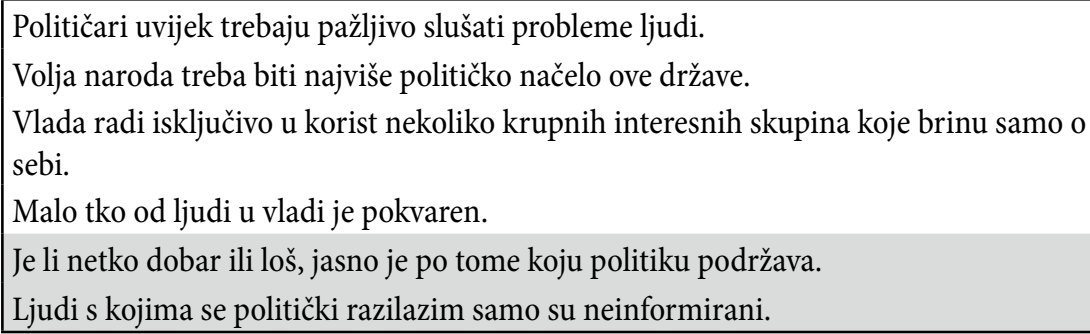

Napomena: osjenčene su čestice isključene iz analize. Čestice 4. i 6. izvorno su bile kodirane u suprotnom smjeru te su stoga rekodirane prije konstruiranja ljestvice za potrebe ove analize.

Tablica 9. Ljestvica ekonomskog liberalizma

Osiguranje stambenog prostora i njegovu cijenu država treba prepustiti tržištu.

Težište obrazovne politike treba biti poticanje najboljih.

Jedino tržište treba odlučiti o opstanku radnih mjesta. 


\title{
The Cleavage Structure and parliamentary elections in Croatia in $\mathbf{2 0 2 0}$ in times of pandemic
}

\begin{abstract}
The article employs an electoral field survey to examine the social cleavages structure in Croatia in the context of the 2020 parliamentary election. Based on a multinomial logistic regression, the article assesses previous findings about a value cleavage rooted in religion, and an identity cleavage founded on views of the past, which combined make up the cultural dimension of party competition. The article also tests for a possible emergence of a new social cleavage, entrenched in voter opinions on economic issues, as well as cleavages pertaining to the issues of sovereignism and demands for more democratic participation. This study introduces new predictive scales which were not previous used in similar studies of Croatian elections. The evaluation of the proposed regression model has shown that religiosity and views of the past are still dominant predictors of voter behavior in Croatia. In addition, significant age differences were detected, whereby younger voters have a higher probability of supporting the Homeland Movement or abstaining, while older voters have greater chances of choosing the center-left coalition. The results also show that higher values on the populism scale lead to lower probability of voting for HDZ, the main center-right party. In conclusion, the article confirms the stability of the value and identity cleavages, as well as the significance of religion and the past, while not detecting the existence of an economic cleavage.
\end{abstract}

Key words Croatia, parliamentary elections, social cleavages, voter behavior, political parties 